Case Report

\title{
Efficacy of Single Tocilizumab Administration in an 88-Year-Old Patient with Severe COVID-19 and a Mini Literature Review
}

Cid Ould Ouali ${ }^{1}$, Nadia Ladjouzi ${ }^{1}$, Khidher Tamas ${ }^{1}$, Hendriniaina Raveloson ${ }^{1}$, Jihene Ben Hassen ${ }^{1}$, Nesrine El Omeiri ${ }^{1}$, Georges Zouloumis ${ }^{1}$, Mohamed Moataz Al Zoabi ${ }^{1}$, Muneer Asadi ${ }^{1}$, Aziza Jhouri ${ }^{2}$ and Joël Schlatter ${ }^{2, * \mathbb{B}}$

Citation: Ould Ouali, C.; Ladjouzi, N.; Tamas, K.; Raveloson, H.; Ben

Hassen, J.; El Omeiri, N.; Zouloumis, G.; Al Zoabi, M.M.; Asadi, M.; Jhouri, A.; et al. Efficacy of Single Tocilizumab Administration in an 88-Year-Old Patient with Severe COVID-19 and a Mini Literature Review. Geriatrics 2022, 7, 22. https://doi.org/10.3390/geriatrics 7010022

Academic Editor: Jonathan Hewitt

Received: 12 January 2022

Accepted: 18 February 2022

Published: 21 February 2022

Publisher's Note: MDPI stays neutral with regard to jurisdictional claims in published maps and institutional affiliations.

Copyright: (c) 2022 by the authors. Licensee MDPI, Basel, Switzerland. This article is an open access article distributed under the terms and conditions of the Creative Commons Attribution (CC BY) license (https:// creativecommons.org/licenses/by/ $4.0 /)$.
1 Department of Post-Acute and Rehabilitation Care, Department of Critical Geriatric Medicine, Hospital of Paul Doumer, Assistance Publique des Hôpitaux de Paris (AP-HP), 60140 Labruyère, France; cid.ouldouali@aphp.fr (C.O.O.); nadia.ladjouzi@aphp.fr (N.L.); khidher.tamas@aphp.fr (K.T.); hendriniaina.raveloson@aphp.fr (H.R.); jihene.benhassen@aphp.fr (J.B.H.); nesrine.elomeiri@aphp.fr (N.E.O.); georges.zouloumis@aphp.fr (G.Z.); mohamedmoataz.alzoabi@aphp.fr (M.M.A.Z.); muneer.asadi@aphp.fr (M.A.)

2 Pharmacy, Hospital of Paul Doumer, Assistance Publique des Hôpitaux de Paris (AP-HP), 60140 Labruyère, France; aziza.jhoury@aphp.fr

* Correspondence: joel.schlatter@aphp.fr

\begin{abstract}
The new coronavirus disease 2019 (COVID-19) could be associated with elevated inflammatory cytokine levels, suggesting the involvement of cytokine release syndrome. This syndrome is characterized by release of interleukin 6 correlated with COVID-19 severity and mortality. Targeting IL-6 with Tocilizumab treatment could be a potential therapeutic option for old patients. We report the case of an 88-year-old man with COVID-19 disease who presented at the admission with anemia, fever, oxygen desaturation (92\%), and inflammatory syndrome (C-reactive protein (CRP) at $182.5 \mathrm{mg} / \mathrm{L}$; reference range $<5.0 \mathrm{mg} / \mathrm{L})$. After remaining CRP level increase $(206.6 \mathrm{mg} / \mathrm{L})$, Tocilizumab administration led to rapid clinical outcome and resolution of his inflammatory syndrome. This case report represents a supplementary data confirming the efficacy and safety of Tocilizumab for COVID-19 in elderly patients.
\end{abstract}

Keywords: COVID-19; Tocilizumab; case report; elderly; inflammatory syndrome

\section{Introduction}

The new coronavirus pneumonia, first identified in the province of Hubei (China) and designated by the World Health Organization (WHO) as coronavirus disease 2019 (COVID-19), induced a viral infection by severe acute respiratory syndrome coronavirus 2 (SARS-CoV-2) that affected several organs involving the respiratory, renal, cardiovascular, central nervous, and gastrointestinal systems [1,2]. This multi organ dysfunction syndrome could be explained by the immune dysregulation caused by the SARS-CoV-2, resulting in hyperinflammation on the immune systems and cytokine release syndrome (cytokine storm) $[3,4]$. In this context, elderly patients are more likely to experience a more severe course of disease due to alterations in both the innate and adaptative immune systems [5]. In advanced age, it has been reported that an increase in the levels of circulating proinflammatory cytokines such as interleukins, growth factors, and proteases [6,7]. These elements could contribute to develop severe disease in elderly adults over 65 years old that represent $80 \%$ of the hospitalizations with a higher risk of death than those under 65 [5]. Older adults with severe COVID-19 could rapidly progress into a cytokine storm that involves hyperactivation of the immune system and hypercoagulation in the small blood vessels [8]. 
Because COVID-19 severity and mortality are correlated with the high levels of interleukin-6 (IL-6), administration of Tocilizumab, a recombinant monoclonal antibody which binds specifically to IL-6 receptors, was used with a decrease in fever, lower oxygen requirements, and a reduction in mortality [9-12]. However, few data exist on the effectiveness and safety of the drug treatment in elderly patients $[13,14]$.

In this case, we describe the successful treatment by single Tocilizumab administration of an 88-year-old patient with severe COVID-19.

\section{Case}

An 88-year-old man was admitted in our geriatric rehabilitation unit after a blood transfusion for anemia at $5 \mathrm{~g} / \mathrm{L}$. The past medical history of the patient included epilepsy, ischemic heart failure treated, arterial hypertension, dyslipidemia, and obesity. At baseline, he had partial deafness and was brought to medical attention due to loss of autonomy for personal hygiene and dressing. After the admission, asymptomatic SARS-CoV-2 infection was confirmed by reverse transcription polymerase chain reaction (RT-PCR) test and the patient was transferred to our COVID-19 unit. He had sustained fever $\left(38^{\circ} \mathrm{C}\right)$, heart rate at $100 / \mathrm{min}$, blood pressure at $142 / 65 \mathrm{mmHg}$, and the peripheral capillary oxygen saturation (SpO2) rose to $92 \%$ by $2 \mathrm{~L} / \mathrm{min}$ oxygen. At the same time, blood sample analysis found elevated levels of C-reactive-protein (CRP $182.5 \mathrm{mg} / \mathrm{L}$ ) a high marker of inflammation, an anemia (hemoglobin $10.8 \mathrm{~g} / \mathrm{dL})$, hyponatremia (132 mmol/L), hyperkalemia $(4.53 \mathrm{mmol} / \mathrm{L})$, and hyperuricemia $(11.8 \mathrm{mmol} / \mathrm{L})$. The patient received paracetamol $(3 \mathrm{~g} /$ day $)$, ramipril ( $5 \mathrm{mg} /$ day), and lansoprazole ( $15 \mathrm{mg} /$ day). Table 1 shows the main laboratory values made to date.

Table 1. Main laboratory values made to date.

\begin{tabular}{|c|c|c|c|c|}
\hline Parameters (Laboratory Reference) & Admission & Day 2 & Day 8 & Day 13 \\
\hline $\mathrm{CRP}(<5.0 \mathrm{mg} / \mathrm{L})$ & 182.5 & 176.8 & 206.6 & 23.3 \\
\hline Hemoglobin (12.9-16.7 g/dL) & 10.8 & 10.7 & 9.9 & 10.0 \\
\hline Natremia (136-145 mmol/L) & 132 & 135 & 137 & 139 \\
\hline Kalemia (3.40-4.50 mmol/L) & 4.53 & 4.56 & 4.38 & 3.75 \\
\hline Lymphocytes (1.070-4.100 g/L), & 1.470 & 1.010 & 0.690 & 0.48 \\
\hline Blood creatinine $(62.0-106.0 \mu \mathrm{mol} / \mathrm{L})$ & 99.9 & 103.3 & 78.4 & 88.1 \\
\hline Blood urea $(2.86-8.21 \mathrm{mmol} / \mathrm{L})$ & 11.8 & 12.9 & 8.2 & 7.1 \\
\hline $\operatorname{MDRD}^{1}(>90)$ & 62 & 60 & 82 & 72 \\
\hline NT-proBNP ${ }^{2}(50.0-125.0 \mathrm{pg} / \mathrm{mL})$ & & - & 9118.0 & 3819.0 \\
\hline
\end{tabular}

${ }^{1}$ MDRD: modification of diet in renal disease ${ }^{2}$ NT-proBNP: pro-brain natriuretic peptide.

On day 2, he presented a sudden oxygen desaturation (SpO2 90\%) stabilized with the administration of oxygen at high flow $(4 \mathrm{~L} / \mathrm{min})$. The thoracic radiography showed an alveolar and interstitial diffuse damage and a left basal outpouring (Figure 1).

At this time, the patient received dexamethasone (6 mg daily for 10 days), enoxaparin (4000 UI daily for 30 days), and combination of amoxicillin and clavulanic acid ( $1 \mathrm{~g} / 200 \mathrm{mg}$ $\times 3$ /day for 2 days) as the recommendations for the therapeutic management of COVID patients from the Paris University Hospitals (AP-HP) and the European Respiratory Society guideline. On day 3 , a computed tomography angiogram of the chest was ordered and revealed left segmental pulmonary emboli without sign of pulmonary arterial hypertension (Figure 2).

On day 4 , spiramicin ( 3 MUI $\times 3$ /day) was added and ceftriaxone $1 \mathrm{~g}$ daily to treat a urinary tract infection to Morganella morgana. The combination of amoxicillin and clavulanic acid was stopped without impact on the fever. By hospital day 8, its clinical state was judged to be critical with persistent high fever $\left(38.9^{\circ} \mathrm{C}\right)$, blood pressure at $147 / 59 \mathrm{mmHg}$, heart rate $86 / \mathrm{min}$, oxygen saturation $90 \%$ with $5 \mathrm{~L} / \mathrm{min}$, and high level of CRP $206.6 \mathrm{mg} / \mathrm{L}$. Figure 3 summarizes major clinical parameters and CRP levels obtained during the hospital course. 


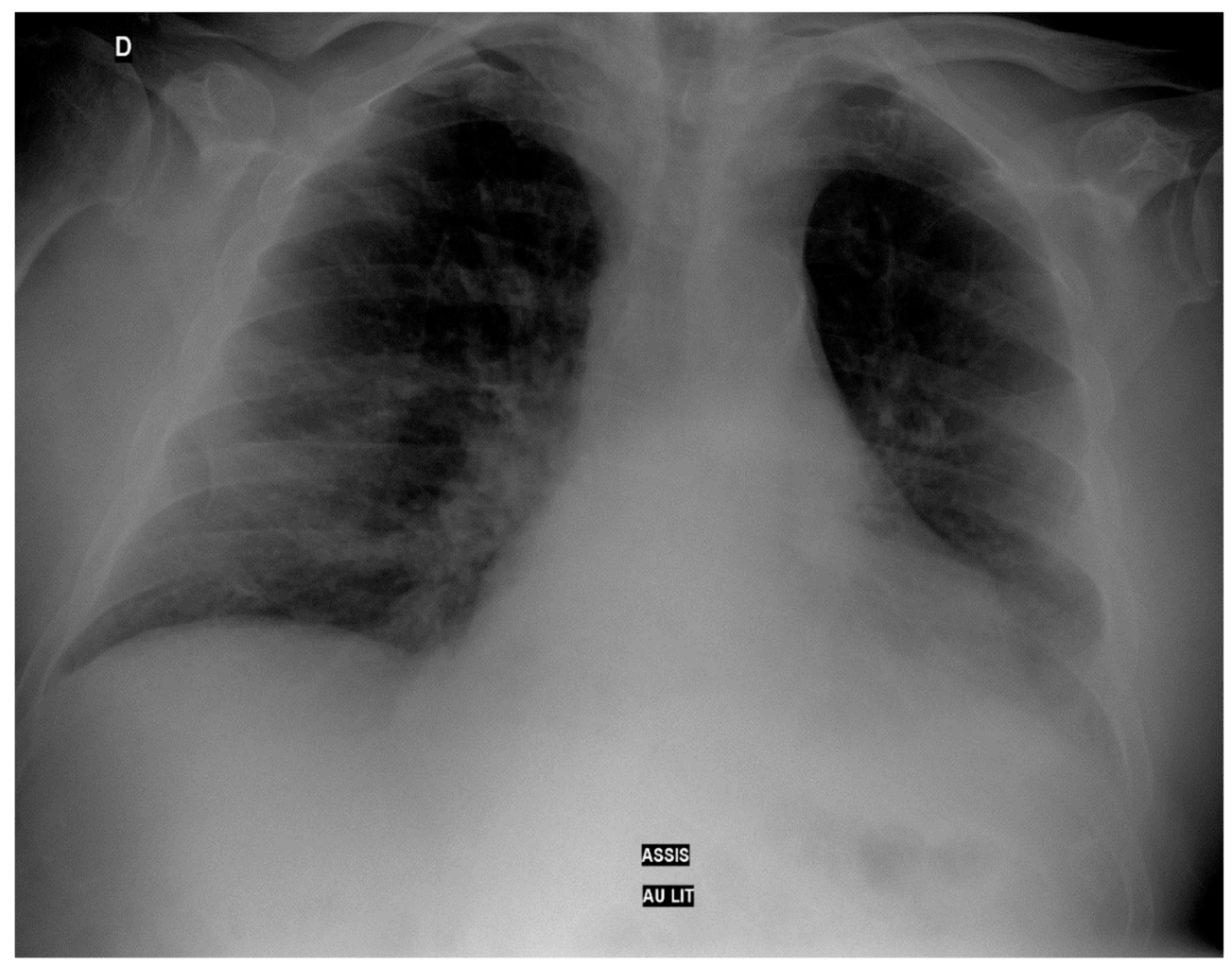

Figure 1. Thoracic radiography at day 2.

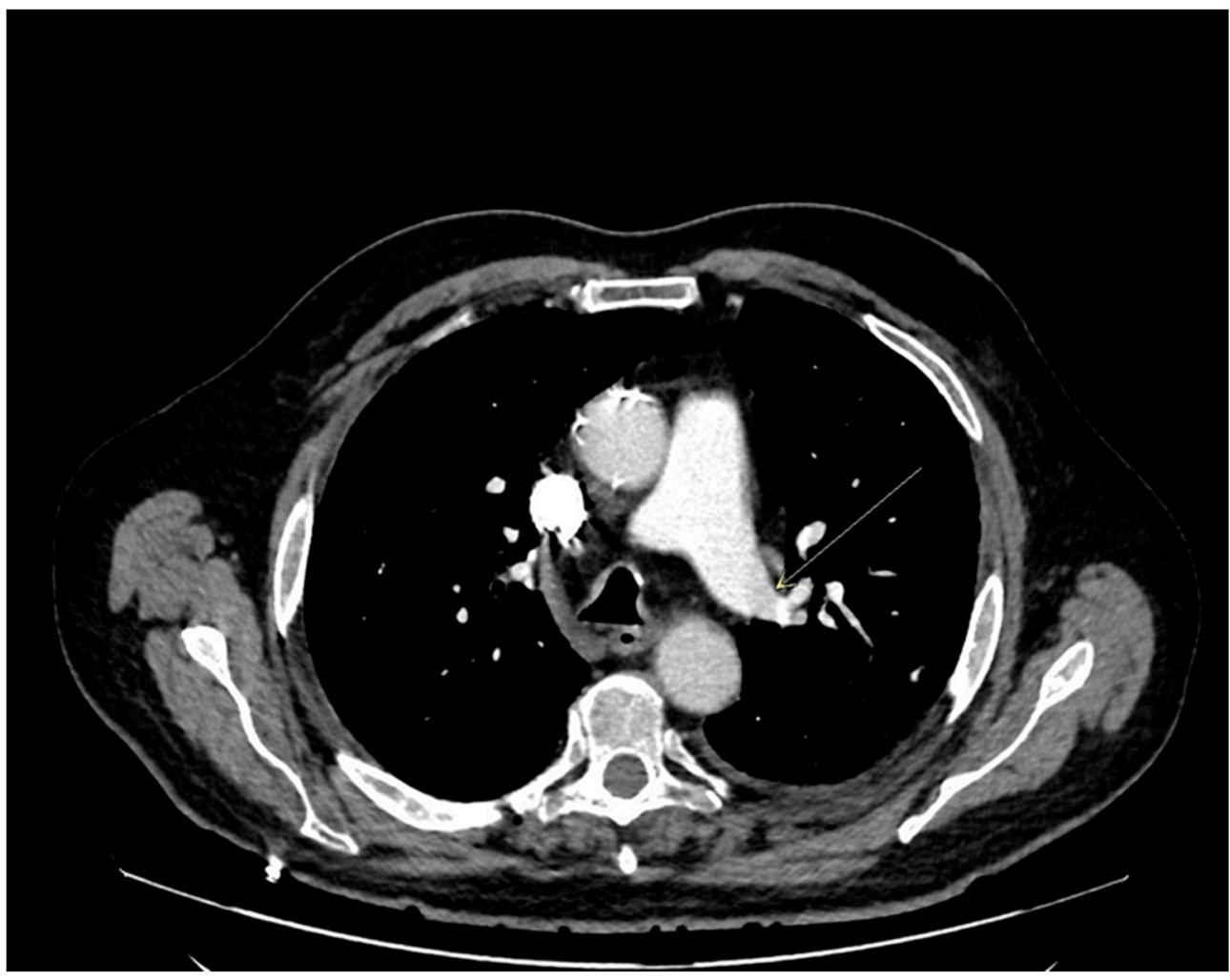

Figure 2. Computed tomography angiogram of the chest at day 3. (arrow shows the emblism). 


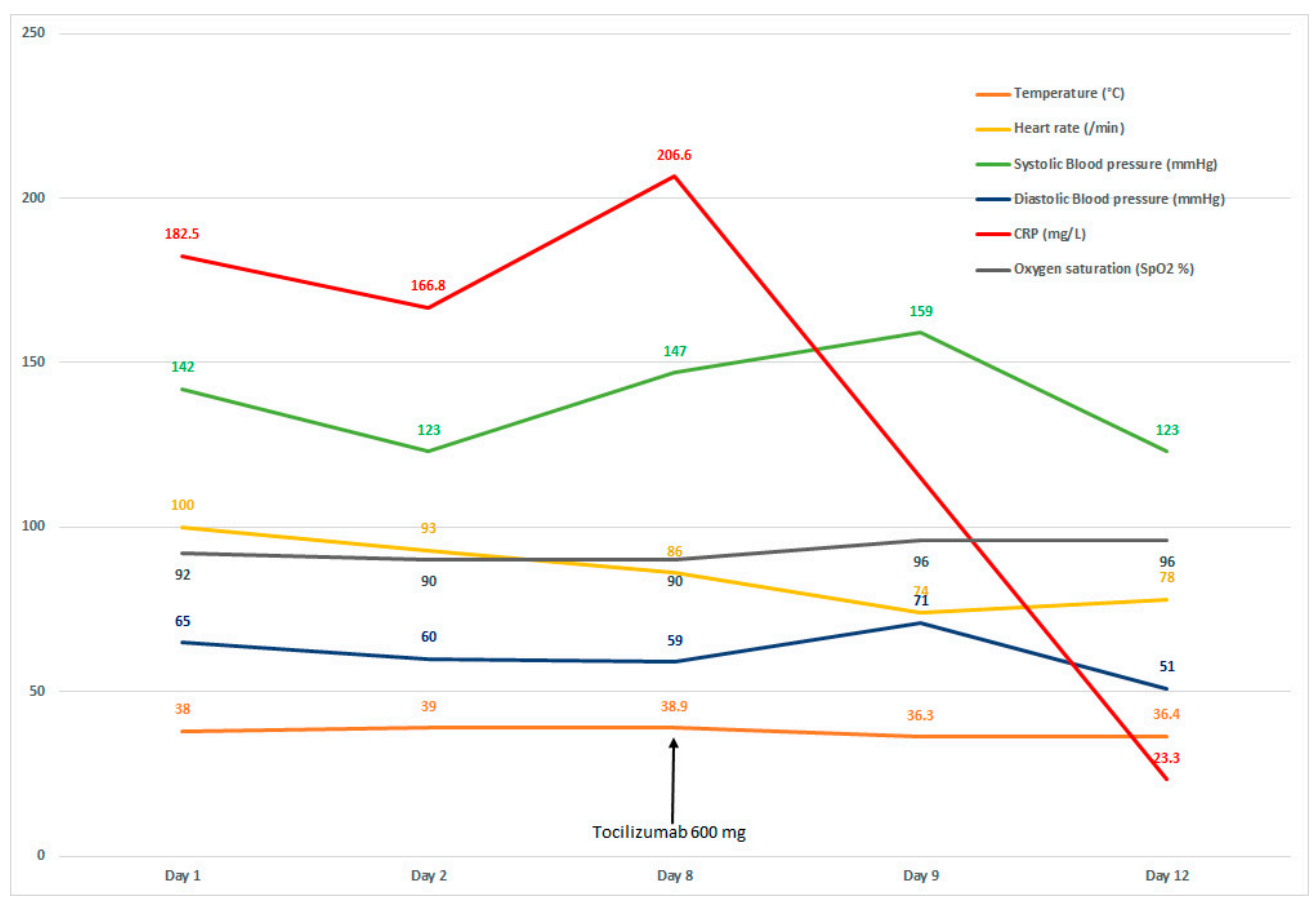

Figure 3. Clinical parameters from day 1 to day 12 (Tocilizumab administration at day 8).

At this time, the choice of Tocilizumab treatment was discussed and validated in a multidisciplinary meeting with geriatricians and clinical pharmacists.

The patient received a single dose of intravenous Tocilizumab at $8 \mathrm{mg} / \mathrm{kg}(600 \mathrm{mg})$ with no clinical improvement. The same day, the clinical state of the patient progressed favorably with normal temperature at $36.3{ }^{\circ} \mathrm{C}$, heart rate $74 / \mathrm{min}$, and blood pressure $159 / 71 \mathrm{mmHg}$. The CRP level was significantly decreased to $23.3 \mathrm{mg} / \mathrm{L}$ after 5 days of drug administration and normalized at day 10 of drug administration. The oxygen saturation was increased more progressively, and the oxygen discharge was effective by day 28 after the Tocilizumab administration. Four weeks later, the patient was seen in an out-patient setting and had been doing well.

\section{Discussion}

We report the case of an 88-year-old man with risk factors including an older age that was treated successfully by Tocilizumab for a severe COVID-19 disease. Clinical data showed that the patient's vital parameters improved after drug treatment. Moreover, a significant decrease in CRP and fever levels was observed just after a single infusion, suggesting the potential impact of Tocilizumab on the cytokine release syndrome. Therefore, our patient did not experience any adverse events.

Because studies in severe COVID-19 observed the association with elevated levels of IL-6 and mortality, randomized clinical trials suggested benefit of the anti-IL-6 receptor monoclonal antibody Tocilizumab with reported heterogenous results [15-19]. In a randomized clinical trial that included 130 patients hospitalized with COVID-19 and moderate-to-severe pneumonia, Tocilizumab did not reduce the mortality over 28 days in comparison with the usual care group [16]. These results were supported by the study by Tsai et al. on the impact of Tocilizumab administration on mortality in severe COVID-19 that recorded no statistical difference between the Tocilizumab group and the no Tocilizumab group (odds ratio, 1.0; $95 \%$ confidence interval, $0.465-2.151 ; p=1.00$ ) [20]. In a recent research article, a trial that examined survival varied with baseline CRP levels demonstrated the administration of Tocilizumab was beneficial in patients with CRP levels greater than $15.0 \mathrm{~g} / \mathrm{L}$ [21]. Some studies have also evaluated the Tocilizumab treatment in patients with severe COVID-19, suggesting its efficacy on mortality [22-24]. The TCZ efficacy on mortality on day 14 and 
28 was retrospectively evaluated in 62 patients ( $57.4 \pm 14.3$ years) who received one to two doses of TCZ (400-800 mg every $12 \mathrm{~h}$ ) [22]. There was a significant difference in the 28 -day $(\mathrm{TCZ}=62$ and control $=86)$ and in the 14 -day $(9.7 \%$ vs. $24.4 \%, p=0.022)$ fatality rate among the TCZ-treated patients and control group. The inflammatory marker CRP decreased in the TCZ-treated patients, indicating a response to the IL- 6 blocker. Moreover, a meta-analysis including 10 studies involving 1675 severe COVID-19 patients (median age $>52$ years) revealed a significant difference in mortality in the Tocilizumab group compared to the control group (19.5\% vs. $28.3 \%, p<0.00001)$ [24]. As in our clinical case, a Spanish cohort of elderly COVID-19 patients (mean age 85.2 years) found benefit in patients receiving Tocilizumab and corticosteroids (adjusted estimation HR 0.09, 95\% CI: 0.01-0.74) [23]. Elderly patients are frequently absent from clinical trials even though we need efficacy and safety data in this population. More information is needed regarding the dose schedule of Tocilizumab treatment, eligibility criteria to select the patients, and association with other therapeutic options such as corticosteroids or antiviral drugs.

\title{
4. Conclusions
}

In conclusion, Tocilizumab may be an optional treatment in elderly patients with severe COVID-19 associated with high CRP level. However, further research is needed to identify optimal elderly patient population for treatment with Tocilizumab, and to confirm its effectiveness and safety.

\begin{abstract}
Author Contributions: C.O.O. and J.S. decided study design and concept, drafted manuscript; N.L. revised manuscript; K.T. revised manuscript; H.R. revised manuscript; J.B.H. revised manuscript; N.E.O. revised manuscript; G.Z. revised manuscript; M.M.A.Z. revised manuscript; M.A. revised manuscript; A.J. revised manuscript; J.S. decided study design and concept, provided study supervision, revised manuscript. All authors have read and agreed to the published version of the manuscript.
\end{abstract}

Funding: This research received no external funding.

Institutional Review Board Statement: This study was conducted in accordance with the Declaration of Helsinki. As a single case report, ethical review and approval was not applicable.

Informed Consent Statement: Informed consent was obtained from patient involved in the study.

Data Availability Statement: The data presented in this study can be requested to the corresponding author. The data are not publicly available due to confidentiality and anonymity.

Conflicts of Interest: All authors declare no conflict of interest.

\section{References}

1. Huang, C.; Wang, Y.; Li, X.; Ren, L.; Zhao, J.; Hu, Y.; Zhang, L.; Fan, G.; Xu, J.; Gu, X.; et al. Clinical features of patients infected with 2019 novel coronavirus in Wuhan, China. Lancet 2020, 395, 497-506. [CrossRef]

2. Zhou, P.; Yang, X.L.; Wang, X.G.; Hu, B.; Zhang, L.; Zhang, W.; Si, H.R.; Zhu, Y.; Li, B.; Huang, C.L.; et al. A pneumonia outbreak associated with a new coronavirus of probable bat origin. Nature 2020, 579, 270-273. [CrossRef] [PubMed]

3. Jiang, F.; Deng, L.; Zhang, L.; Cai, Y.; Cheung, C.W.; Xia, Z. Review of the Clinical Characteristics of Coronavirus Disease 2019 (COVID-19). J. Gen. Intern. Med. 2020, 35, 1545-1549. [CrossRef] [PubMed]

4. Wang, D.; Hu, B.; Hu, C.; Zhu, F.; Liu, X.; Zhang, J.; Wang, B.; Xiang, H.; Cheng, Z.; Xiong, Y.; et al. Clinical Characteristics of 138 Hospitalized Patients with 2019 Novel Coronavirus-Infected Pneumonia in Wuhan, China. JAMA 2020, 323, 1061-1069. [CrossRef] [PubMed]

5. $\quad$ Chinnadurai, R.; Ogedengbe, O.; Agarwal, P.; Money-Coomes, S.; Abdurrahman, A.Z.; Mohammed, S.; Kalra, P.A.; Rothwell, N.; Pradhan, S. Older age and frailty are the chief predictors of mortality in COVID-19 patients admitted to an acute medical unit in a secondary care setting- a cohort study. BMC Geriatr. 2020, 20, 409. [CrossRef]

6. Franceschi, C.; Garagnani, P.; Parini, P.; Giuliani, C.; Santoro, A. Inflammaging: A new immune-metabolic viewpoint for age-related diseases. Nat. Rev. Endocrinol. 2018, 14, 576-590. [CrossRef]

7. Schmeer, C.; Kretz, A.; Wengerodt, D.; Stojiljkovic, M.; Witte, O.W. Dissecting Aging and Senescence-Current Concepts and Open Lessons. Cells 2019, 8, 1446. [CrossRef]

8. Terpos, E.; Ntanasis-Stathopoulos, I.; Elalamy, I.; Kastritis, E.; Sergentanis, T.N.; Politou, M.; Psaltopoulou, T.; Gerotziafas, G.; Dimopoulos, M.A. Hematological findings and complications of COVID-19. Am. J. Hematol. 2020, 95, 834-847. [CrossRef] 
9. Li, H.; Liu, L.; Zhang, D.; Xu, J.; Dai, H.; Tang, N.; Su, X.; Cao, B. SARS-CoV-2 and viral sepsis: Observations and hypotheses. Lancet 2020, 395, 1517-1520. [CrossRef]

10. Zhang, X.; Tan, Y.; Ling, Y.; Lu, G.; Liu, F.; Yi, Z.; Jia, X.; Wu, M.; Shi, B.; Xu, S.; et al. Viral and host factors related to the clinical outcome of COVID-19. Nature 2020, 583, 437-440. [CrossRef]

11. Napoli, C.; Benincasa, G.; Criscuolo, C.; Faenza, M.; Liberato, C.; Rusciano, M. Immune reactivity during COVID-19: Implications for treatment. Immunol. Lett. 2021, 231, 28-34. [CrossRef]

12. Ali, A.; Kamjani, M.H.; Kesselman, M.M. The Role of Tocilizumab in Cytokine Storm and Improving Outcomes in COVID-19. Recent Pat. Antiinfect. Drug Discov. 2020, 15, 104-112. [CrossRef]

13. Streicher, C.; Engalenc, X.; Gaudin, M.; Vignaud, G.; Daulange, A.; Abraham, B. Could Tocilizumab be an Attractive Therapeutic Option for Elderly Patients with Severe COVID-19? A Case Report. Clin. Drug Investig. 2020, 40, 1085-1088. [CrossRef]

14. Kataoka, H.; Kodama, F.; Tomita, T.; Kondo, M.; Nagasaka, A.; Nishikawa, S.; Mukai, M. Immediate Amelioration of Severe Respiratory Distress in Sjögren's Syndrome with COVID-19 Treated with a Single Dose of Off-label Tocilizumab. Intern. Med. 2021, 60, 639-643. [CrossRef] [PubMed]

15. REMAP-CAP Investigators; Gordon, A.C.; Mouncey, P.R.; Al-Beidh, F.; Rowan, K.M.; Nichol, A.D.; Arabi, Y.M.; Annane, D.; Beane, A.; van Bentum-Puijk, W.; et al. Interleukin-6 Receptor Antagonists in Critically Ill Patients with COVID-19. N. Engl. J. Med. 2021, 384, 1491-1502.

16. Hermine, O.; Mariette, X.; Tharaux, P.L.; Resche-Rigon, M.; Porcher, R.; Ravaud, P.; CORIMUNO-19 Collaborative Group. Effect of Tocilizumab vs. Usual Care in Adults Hospitalized with COVID-19 and Moderate or Severe Pneumonia: A Randomized Clinical Trial. JAMA Intern. Med. 2021, 181, 32-40. [CrossRef] [PubMed]

17. Stone, J.H.; Frigault, M.J.; Serling-Boyd, N.J.; Fernandes, A.D.; Harvey, L.; Foulkes, A.S.; Horick, N.K.; Healy, B.C.; Shah, R.; Bensaci, A.M.; et al. BACC Bay Tocilizumab Trial Investigators. Efficacy of Tocilizumab in Patients Hospitalized with Covid-19. N. Engl. J. Med. 2020, 383, 2333-2344. [CrossRef] [PubMed]

18. Salvarani, C.; Dolci, G.; Massari, M.; Merlo, D.F.; Cavuto, S.; Savoldi, L.; Bruzzi, P.; Boni, F.; Braglia, L.; Turrà, C.; et al. RCT-TCZCOVID-19 Study Group. Effect of Tocilizumab vs. Standard Care on Clinical Worsening in Patients Hospitalized with COVID-19 Pneumonia: A Randomized Clinical Trial. JAMA Intern. Med. 2021, 181, 24-31. [CrossRef] [PubMed]

19. Salama, C.; Han, J.; Yau, L.; Reiss, W.G.; Kramer, B.; Neidhart, J.D.; Criner, G.J.; Kaplan-Lewis, E.; Baden, R.; Pandit, L.; et al. Tocilizumab in Patients Hospitalized with Covid-19 Pneumonia. N. Engl. J. Med. 2021, 384, 20-30. [CrossRef] [PubMed]

20. Tsai, A.; Diawara, O.; Nahass, R.G.; Brunetti, L. Impact of tocilizumab administration on mortality in severe COVID-19. Sci. Rep. 2020, 10, 19131. [CrossRef]

21. Mariette, X.; Hermine, O.; Tharaux, P.L.; Resche-Rigon, M.; Steg, P.G.; Porcher, R.; Ravaud, P. Effectiveness of Tocilizumab in Patients Hospitalized with COVID-19: A Follow-up of the CORIMUNO-TOCI-1 Randomized Clinical Trial. JAMA Intern. Med. 2021, 181, 1241-1243. [CrossRef] [PubMed]

22. Al-Baadani, A.; Eltayeb, N.; Alsufyani, E.; Albahrani, S.; Basheri, S.; Albayat, H.; Batubara, E.; Ballool, S.; Al Assiri, A.; Faqihi, F.; et al. Efficacy of tocilizumab in patients with severe COVID-19: Survival and clinical outcomes. J. Infect. Public. Health. 2021, 14, 1021-1027. [CrossRef] [PubMed]

23. Duarte-Millán, M.A.; Mesa-Plaza, N.; Guerrero-Santillán, M.; Morales-Ortega, A.; Bernal-Bello, D.; Farfán-Sedano, A.I.; García de Viedma-García, V.; Velázquez-Ríos, L.; Frutos-Pérez, B.; De Ancos-Aracil, C.L.; et al. Prognostic factors and combined use of tocilizumab and corticosteroids in a Spanish cohort of elderly COVID-19 patients. J. Med. Virol. 2021, in press. [CrossRef] [PubMed]

24. Zhao, J.; Cui, W.; Tian, B.P. Efficacy of tocilizumab treatment in severely ill COVID-19 patients. Crit. Care 2020, 24, 524. [CrossRef] 